\title{
Marketing in Banking Sector and Digital Ecosystems
}

\author{
Veronika Lizovskaya \\ Marketing Department \\ St. Petersburg State University of Economics \\ St. Petersburg, Russia \\ Lizovskaya.vv@mail.ru
}

\author{
Iana Salikhova \\ Marketing Department \\ St. Petersburg State University of Economics \\ St. Petersburg, Russia
}

\author{
Ekaterina Khalina \\ Assistant, Marketing Department \\ St. Petersburg State University of Economics \\ St. Petersburg, Russia
}

\begin{abstract}
Currently, the banking sector is undergoing significant changes due to the development of digital technologies and changes in consumer behavior. In the context of increased competition, banks are looking for new ways to attract and retain customers, focusing on omnichannel service strategies and the development of a digital ecosystem. Thus, there is a need for additional research on customer experience and identification of the most promising areas of interaction with customers in the banking sector. The authors conducted a qualitative study, which included 4 focus groups and 6 in-depth interviews with participants of different ages, as well as a pilot quantitative study of the users most involved in using digital services. The results of the study made it possible to design a customer journey map for different categories of clients, to identify the most significant digital services and potential requests regarding existing and promising platforms and marketplaces.
\end{abstract}

Keywords: marketing in banking sector, digital ecosystem, consumer experience

\section{INTRODUCTION}

Dynamic of innovation process has become a key feature of the banking sector that ensures the competitiveness of market participants. Moreover, it affects the operational processes in the banking sector, the services provided and the mechanisms used to interact with customers under the conditions of their digital transformation. 2019:

The main trends of the Russian banking sector in 2018-

- digitalization of business processes of banks and customer interaction channels,

- a strong impact on the banking services market has a change in consumer behavior and competition from large companies that are actively introducing innovations;
- the use of Big Data technology and artificial intelligence, biometric technologies to collect customer information, improving services and providing personalized services;

- increased investment in cybersecurity.

In addition, among the innovations of the recent years in the banking sector can be mentioned the use of remote identification mechanisms, the National Payment Card System (NSPK), the introduction of the Quick Payment System (SBP), aimed at providing real-time payments and transfers for goods and services, 24 / 7 / 365 using simple identifiers of the payee between individuals, and then legal entities.

With the active participation of the Bank of Russia, a system of introducing innovative solutions in the banking sector is being formed, including the development of a citizen digital profile, which should allow managing data and operations online, the possibility of accounting for electronic invoices, digital bank guarantees, digital letters of credit.

In addition, there is a change in consumer behavior and their reaction to the implementation of digital technologies in the bank's activities. Consumers are actively using new banking products and interaction channels that allow them to improve their customer experience and meet their needs. A modern consumer has access to the information about banking products, the quality of service and experience of other customers, in order to compare them and easily switch to competing offers. Thus, banks actively seek ways to increase consumer value. One of the relevant areas associated with the study concern with customer experience, identifying touchpoints, promising services in the development of the bank digital ecosystem.

The article presents the results of a qualitative and quantitative study of banking services consumers in St. Petersburg market, as well as case analysis of Russian banks 
developing a digital ecosystem. Based on the study, conclusions and recommendations are developed in the areas of improving the work of banking structures to improve customer experience.

\section{LITERATURE REVIEW AND RESEARCH METHODOLOGY}

\section{A. Literature Review}

The studies were conducted at the enterprise AnzheroWorks in bank marketing appeared in early-2000's tended to take a focus on relationship marketing with IT-services implementation. Possibilities to apply relationship marketing tools to the retail financial services have been studied by Dibb and Meadows [1]. The same idea can be found in the research done by Colgate [2] in Australia, New Zealand, UK and Ireland, showing the trend to a greater emphasis on bank marketing activities and the need of supporting it with ITservices implementation.

Some authors focused on the bank marketing on specific geographic markets. Flohr Nielsen and Kock [3] described the barriers for transition from «listen to consumer» to «controlling with customer focus» in Nordic financial services. The question of customer switching behavior in the New Zealand banking industry first raised by Clemes, Gan and Zheng [4] started the range of the same researches on other markets: South Africa [5], Asia [6], Jordan [7], etc.

In the study of B2B marketing in banking Theron, Terblanche and Boshoff [8] found the possibility for transformation through development of some well-established individual intentions into broader attitude as drivers of longterm relationship building in $\mathrm{B} 2 \mathrm{~B}$ sphere.

The research of Andreeva and Sviridov [9] covers tools aimed at strengthening the global and national financial and credit systems, including the marketing management methods leading to the financial stability.

As part of the research on performance evaluation and marketing strategy construction, Novenkova, Shakirzyanov and Gilmanova [10] studied differences of Private banking trend (or VIP servicing facility) comparing marketing strategy with mass-market solutions.

Online and mobile banking became a main focus of a lot of researches starting from 2005. According to Lassar and Manolis [11] there's positive relationship between internet related innovativeness and online banking. Also, the authors found that contrary general innovativeness is negatively related to online banking. Based on an empirical study in the field of e-banking, H. Bauer, M. Hammerschmidt and T. Falk [12] suggested a measurement model to the bank web site quality check using the following factors: security, trust, basic services quality, cross-buying services quality, added value, transaction support and responsiveness. Chemingui and Lallouna [13] identified barriers and motivating factors affecting the willingness and desire to use mobile financial services. They reported that one resistance dimension can be found (tradition) and four motivation factors, such as compatibility, trialability, perceived enjoyment and system quality. In addition, authors mentioned that system quality has a significant and positive impact on trust. Jiménez and AguiarDíaz [14] reported that there is «a positive relationship between a higher educational level, gender, level of income, being self-employed, greater use of ATMs, greater frequency in the use of banking operations and the use of Internet banking. On the contrary, age exhibits a negative relationship». According to Boateng et al. [15], the social environment of the individual, knowledge and beliefs about what it can provide to meet their personal goals are the factors influencing adoption of the new technologies in internet banking.

Recent works began to pay more attention to managing bank reputation and customer satisfaction. Ruiz and García [16] explored the moderating role of culture in terms of customer-based bank reputation in the countries with different cultural patterns. Golovkova et al. [17] examined the relationship between the financial performance of the banking sector and Extended Performance Satisfaction Index (EPSI) for seven European countries over the period 2004-2014.

\section{B. Banking Sector Dinamics and Problem Decsription}

Banking sector in Russian Federation shows positive dynamics in the last few years. According to the Central Bank, the growing importance of the banking sector has increased significantly over the past two decades. Thus, at the end of 2018 , the total assets of the banking sector increased by $10.6 \%$ (from 85 to 94 trillion). The amount of capital of the banking sector increased by $9.9 \%$ in 2018 up to 10.3 trillion rubles. [18]

In the conditions of gradual transition of the population of the country from the savings model of behavior to the consumption, the size of deposits is slightly reduced (by $0.3 \%$ ), while the growth of loans by $10.7 \%$.

In 2018, the banking sector received a profit of 1.34 trillion rubles, 1.7 times higher than the result of 2017 (790 billion rubles).

The share of profitable credit institutions in comparison with 2017 increased from 75 to $79 \%$. Profit in the amount of 1.9 trillion rubles showed 384 credit organizations (in 20171.6 trillion rubles and 421 credit organizations, respectively). With losses in the amount of 575 billion rubles, 100 credit institutions completed the year $-21 \%$ of the number operating as of 01.01.2019, while in 2017140 credit institutions $(25 \%$ of those operating as of 01.01.2018) suffered losses in the amount of 772 billion rubles.

In 2018 , the number of credit institutions changed by more than $13 \%$ (from 561 to 484 ) both due to revocation of licenses (almost 12\%) and due to reorganization (about 1\%). The number of branches of credit institutions decreased from 890 to 709 (by 20\%). The total number of divisions of large banks decreased by almost $10.5 \%$ (by 3,503 units), while the number of additional offices increased slightly (by $1.2 \%$ - from 20,263 to 20,499 ) and mobile cash points (by $2.9 \%$ - from 275 to 283).

All these changes are primarily related to the development of digital remote services, which lead to the transformation of 


\section{A. Cases of the Leading Russian Banks on Creation of the Digital Ecosystems}

Currently, the banking sector is actively developing digital ecosystems, the examples of such development can be found in such large banks as Sberbank, Gazprombank, VTB and Alfa-Bank. At the same time, only the ecosystem of Sberbank and Tinkoff Bank really exist.

The cost of developing the ecosystem is still difficult to estimate, as any innovative solution created over a fairly long period of time (from 5 years). We can expect that it will cost banks tens and hundreds of billion rubles. Thus, the cost of the contract to develop a strategy for the development of partner services (ecosystem) VTB according to the website of public procurement amounted to 158 million rubles. The development of banking ecosystems should contribute to the adoption of the law marketplace, which is being actively discussed in Russia.

The Central Bank is also engaged in the creation of an ecosystem, which should be an online platform for working with products using remote identification, which should allow the following operations: opening deposits, buying bonds and mutual Funds, issuing CTP policies and obtaining a mortgage.

The ecosystem of Tinkoff Bank includes, in particular, a mobile operator, services for search and payment of fines, storage of documents. Also, in the Bank's application is possible to buy tickets to the theater and book a table in the restaurant.

Of particular interest is the ecosystem of Sberbank, which already includes a fairly large set of services, including cellular communication ("Sberbank"), marketplace "Take!", data storage services, credit Bureau, online cinema "OKKO", portal about the city entertainment "Afisha", food delivery service Delivery Club and others. [19]

The idea of developing the ecosystem by Sberbank has been discussed since the end of 2016, which began with the development of a partnership with digital services Yandex and Mail.Ru. in Addition, already at the initial stage of ecosystem development, Sberbank even started a pilot project "Button" for ordering cleaning at home. In the development strategy, Sberbank identified the need to go beyond the sphere of financial services and the formation of an ecosystem based on a broad database of habits, consumption patterns and customer behavior with the development of channels for promoting goods and services and the formation of a technology company on the basis of Sberbank. As a basis for the implementation of the strategy, Sberbank considers the need to form an innovative infrastructure, which also involves the formation of laboratories for the development of artificial intelligence, cybersecurity, robotics, blockchain, the Internet of things, virtual and augmented reality.

Until 2022-2023, it is planned to form the ecosystem of PJSC "VTB", which involves the creation of an IT platform, which will include a rental service, a mobile operator, digital accounting, a marketplace of banking services. [20]

Four digital services are already operating in the pilot mode: VTB mobile virtual operator, Unicom-24 banking 
services marketplace, housing ecosystem and fiscal data operator. Next, it is planned to develop digital accounting and B2B-connection, where small businesses will be able to connect to foreign trading platforms and find suppliers.

The key platform of the developed ecosystem will be the housing ecosystem, designed for the selection, financing, purchasing and registration of real estate, as well as repair and further development. The development of the platform, which will be designed for 10 million users, will be facilitated by digital public services, including electronic registration of real estate.

\section{B. Qualitative Research Results}

Based on the analysis of the results of focus groups, the main points of contact of clients from different categories with banking structures were identified. The maximum number of points of contact was found among the consumers aged from 23 to 60 (65) years, among them: Bank office, ATM, mobile application, Internet banking, e-mail of the client, trade enterprises (when using Bank cards). They use the maximum number of Bank products: Bank cards, both debit and credit, deposits and loans (both consumer and mortgage), deposit insurance and life insurance (not a banking product, but often involves obtaining more favorable conditions for obtaining such banking products as deposits), payment of bills, in addition, it is important for them to get advice on various aspects of the banking offer and the number of examples of interaction with electronic services and offices, it is possible to draw a conclusion about equivalence of information from these two channels. Modern terminology describing new banking services (such as PayPass, NFC (Near Field Communication).

Consumers over the age of 60 (65) mostly noted fewer points of contact: a post office, a Bank office, sometimes an ATM, and a mobile Bank. For them, the use of digital services is more complicated, they choose the most traditional banking products and services: deposits and payment for services. Consulting is most important in the use of ATMs or Bank Deposit terms. The use of new banking products and services for them is problematic, they are not familiar with new technologies and it cause rejection and resistance.

Consumers younger than 23 , who mostly receive income in the form of scholarships and transfers from parents, were less likely to report interactions with staff in Bank offices. The main part of the experience of this group of consumers, described in the focus group process, concerned their interaction through an ATM, mobile application and Internet banking, Bank chats, features of using a Bank card, and more often payments via the Internet, phone or watch. They are familiar with the technology of contactless payments (PayPass), but more preferably is use of NFC technology wireless data transmission of short range, they are familiar with the RFID technology (radio frequency identification), they are extremely interested in new banking services that allow to receive various banking products and services through digital channels of interaction and simplify it.

\section{Quantitative Research Results}

Further, a pilot quantitative study was conducted of the most involved in the use of digital services users aged 19, 20 and 21 years (37, 30 and 33\%, respectively), with $69 \%$ female and $31 \%$ male. The surveyed consumers are University students, most of them are studying, while the distribution on the budget and nonbudget form was 50/50. Some respondents are already working and $11 \%$ of respondents also noted salary among the sources of income (except scholarships and transfers from parents). The majority of the respondents have debit cards $(82 \%)$, however, credit cards are not as common and only $11 \%$ of respondents have them (these are those who do not have a debit card). At the same time, the average number of cards in the hands of respondents is 1.87 cards per person, significantly lower than the level in Russia - 2.65 cards, which is determined by the lack of income in the form of wages and the need for serious, often family spending in this category, and, consequently, salary and credit cards on hand. All respondents mainly use the mobile application, which is the main point of contact of the user with the Bank.

Many respondents still pay in cash (in 50\% of cases), but $20 \%$ of respondents noted that they pay only by the bank card. $38 \%$ of respondents use PayPass technology, 33\% of respondents use ApplePay and SamsungPay technologies.

Among the offered banking services for the respondents, the most attractive are receiving points for purchases and actions (63\% of respondents), discounts when using cards and other banking products (58\% of respondents), cash back (47\%), miles accumulation (37\%).

The respondents were asked what trading enterprises they visit more often and would prefer to see as a partner of the Bank to provide discounts (points accumulation, etc.). First of all, food stores were assigned to this group (77\% of respondents), including Lenta, Okey, Perekrestok, Pyaterochka, which were mainly listed. Also, the respondents are interest in cosmetics and perfumery stores such as Podruzhka, Rivgosh, L'etual, Scarlet (42\% of respondents) and sport goods stores such as Sportmaster and Adidas (25\% of respondents). In addition, respondents are interest in bookstores (Bukvoed), gas stations (Gazpromneft), clothing stores (LoveRepublic).

\section{DISCUSSION}

In the research, there are a number of limitations, which may be directions for further research. The authors focused on a young audience under the age of 23 as the most active in terms of the adoption and use of new technologies. However, consumers belonging to the category of economically active population and an older age group may have different requirements for the development of digital services of banks within their ecosystems.

In this regard, it becomes necessary to study the degree of influence of various factors, including ecosystem services, on customer satisfaction and their further loyalty.

In addition to this, individual studies require the survey of risks and limitations on the use and implementation of 
[4] M.D. Clemes, C. Gan and L.Y. Zheng, "Customer switching behavior in the New Zealand banking industry”, Banks and Bank Systems, vol. 2(4), pp. 50-65, 2007.

of perceived risks from customers.

\section{CONCLUSION}

The modern market of banking services is saturated and in order to increase revenues, banking structures need to improve the offer, adapting it to the needs of consumers developing under the influence of digital transformation. Currently, banks are focused on the formation of a comprehensive offer for different categories of users: corporate clients, individual entrepreneurs and individuals. In order to create an appropriate offer for each category of users, it is important to understand the characteristics of behavior and the real and potential needs in the use of banking products. In addition, a comprehensive proposal on the benefits of using a set of goods and services by the consumer, which can be based only on active interaction between banking structures, trade and services enterprises, can contribute to improving the customer experience. All this determines the need to create an ecosystem that increases value for the client and allows the banking structure to be at the center of customer experience formation.

The most interested group of consumers who will take advantage of the ecosystem and will quickly start to enjoy all the benefits is young people. In addition, consumers aged 23 to 35 years and further from 35 to 45 will become followers who will gradually begin to connect to the new banking services.

The most interesting for the user enterprises to include in the ecosystem are food stores, cosmetics and perfumery stores, sports shops, gas stations.

The extent to which the ecosystem will meet the interests of the user, be convenient and easy to use, will determine in the future and the choice of the Bank by the consumer. Thus, the formation of a digital ecosystem is a priority task to ensure the competitiveness of the banking structure and one of the key trends in banking marketing.

\section{REFERENCES}

[1] S. Dibb and M. Meadows, "The application of a relationship marketing perspective in retail banking", Service Industries Journal, vol. 21(1), pp. 169-194, 2001.

[2] M. Colgate, "Marketing and marketing information system sophistication in retail banking", Service Industries Journal, vol. 20(1), pp. 139-152, 2000.

[3] J. Flohr Nielsen and S. Kock, "From listening to the customer to controlling with customer focus: Facing the barriers in nordic financial services", Service Industries Journal, vol. 23(2), pp. 150-165, 2003.
[5] R. Masocha and T. Matiza, "The role of e-banking on the switching behaviour of retail clients of commercial banks in Polokwane, South Africa”, Journal of Economics and Behavioral Studies, vol. 9(3), pp. 192-200, 2017.

[6] P. Gerrard, and J.B. Cunningham, "Consumer switching behaviour in the Asian banking market", Journal of Service Marketing, vol. 18(3), pp. 215-223, 2004.

[7] A.A.L. Muala, M.A.L. Majali and B. Alkhawaldeh, "Role of marketing information system (MKIS) on banking performance: Case of Jordan", Journal of Internet Banking and Commerce, vol. 18, pp. 1-14, 2013.

[8] E. Theron, N. Terblanche and C. Boshoff, "Building long-term marketing relationships: New perspectives on B2B financial services", South African Journal of Business Management, vol. 44, pp. 33-46, 2013.

[9] L. Andreeva and O. Sviridov, "Experience of Greece on recapitalization of banks, marketing management and personnel retraining in conditions of economic recession", vol. 20, pp. 390-409, 2017.

[10] A. Novenkova, R. Shakirzyanov and A. Gilmanova, "Strategic Marketing Analysis of Premium Package Products of Joint Stock Investment Commercial Bank "Tatfondbank", Asian Social Science, vol. 11, p. 188-192, 2015.

[11] W. Lassar, C. Manolis and S. Lassar, "The relationship between consumer innovativeness, personal characteristics, and online banking adoption", The International Journal of Bank Marketing, vol. 23(2), pp. 176-199, 2005.

[12] H. Bauer, M. Hammerschmidt and T. Falk, "Measuring the quality of ebanking portals", The International Journal of Bank Marketing, vol. 23(2), pp. 153-175, 2005.

[13] H. Chemingui and H. Lallouna, "Resistance, motivations, trust and intention to use mobile financial services", The International Journal of Bank Marketing, vol. 31(7), pp. 574-592, 2013.

[14] J. Jiménez and I. Aguiar-Díaz, "Educational level and Internet banking", Journal of Behavioral and Experimental Finance, vol. 22, pp. 31-40, 2019.

[15] H. Boateng, D. Adam, A. Okoe and T. Anning-Dorson, "Assessing the determinants of internet banking adoption intentions: A social cognitive theory perspective", Computers in Human Behavior, vol. 65, pp. 468478, 2016.

[16] B. Ruiz and J. García, "Modelling customer-based bank reputation: the moderating role of uncertainty avoidance", International Journal of Bank Marketing, vol. 37, pp. 340-361, 2019.

[17] A. Golovkova, J. Eklöf, A. Malova, and O. Podkorytova, "Customer satisfaction index and financial performance: a European cross country study", International Journal of Bank Marketing, Vol. 37(2), pp. 479491, 2019.

[18] Report about the development of banking sector an banking supervision. Central bank of Russia, 2019. Retrieved from: https://www.cbr.ru/Content/Document/File/72560/bsr_2018.pdf (Last

[19] Sberbank development strategy 2020. Retrieved from: https://www.sberbank.ru/common/img/uploaded/files/sberbankdevelop mentstrategyfor2018-2020.pdf (Last accessed: October 31, 2019).

[20] VTB ecosystem. Retrieved from: https://www.vtb.ru/o-banke/presscentr/novosti-i-press-relizy/2019/07/2019-07-19-vyacheslav-dusaleevnaznachen-generalnym-direktorom-zhilishchnoy-ekosistemy-vtb/ (Last accessed: October 31, 2019). accessed: October 31, 2019). 